УДК 377.1

DOI:

Оксана Макогін, викладач

Львівського коледжу будівництва, архітектури та дизайну

\title{
СТВОРЕННЯ ТА ВПРОВАДЖЕННЯ МОДЕЛІ ОРГАНІЗАЦІї ПРАКТИКИ СТУДЕНТІВ БУДІВЕЛЬНИХ КОЛЕДЖІВ
}

У статті обтрунтовано модель організації практики студентів будівельних коледжів та описано ї̈ компоненти. Проаналізовано етапи розробки моделі та визначено їі структуру: педагогічні умови; особливості практики студентів будівельних коледжів; засоби, методи та форми; критерії, показники результатів практики. Представлені узагальнені результати впровадження моделі організації практики студентів будівельних коледжів. Впровадження моделі забезпечує логічну послідовність вибору напрямів діяльності майбутніх будівельників та позитивно вплинуло на рівень параметрів фахових знань та умінь.

Ключові слова: модель; практика; будівельний коледж; майбутні будівельники; педагогічні умови; знання; уміння.

Лim. 5.

Oksana Makohin, Lecturer Lviv College of Civil Engineering, Architecture and Design

\section{CREATION AND IMPLEMENTATION OF A MODEL OF ORGANIZATION OF PRACTICE OF STUDENTS OF CONSTRUCTION COLLEGES}

The article deals with the model of organization of practice of students of building colleges and describes the components of this system. The author analyzes the stages of design of model and defines its structure: pedagogical terms; the features of practice of students of building colleges; the facilities, methods and forms; criteria, indexes of results of practice. The articles presents the generalized results of introduction of model of organization of practice of students of building colleges. An introduction of model provides the logical sequence of choice of directions of activity of future construction and positively influences on the level of parameters of professional knowledge and abilities.

This article consists in the development of model of organization of practice of students-builders. The principle of analogy is used in the process of modeling, based on which in the process of scientific research hypotheses are put forward, that is, prediction, which are built on a relatively small amount of experience data, supervisions, intuitional suppositions, the correctness of which is carried out by experiment.

In the article an author stage-by-stage analysed eight models of organization of Practice of future builders in a college.

An author comes to the conclusion, that development and introduction of model of organization of practice of future builders in colleges allow to provide the logical sequence of choice of directions of activity of future builders, assists formation of complex of the professionally directed abilities and necessary skills for implementation the professional functions. It is experimentally confirmed, that the worked outmodel of organization of practice of future builders serves for the receipt of the results of practical studies.

The generalized practical experience showed, that all types of practical preparation from future speciality assist self-realization.

Keywords: a model; practice; a building college; the future builders; pedagogical conditions: knowledge; skills.

П остановка проблеми та аналіз останніх досліджень. Практика є невід'ємною складовою частиною процесу підготовки майбугніх будівельників. Нормативною базою для проведення практичного навчання студентів $є$ "Положення про проведення практики студентів вищих навчальних закладів України” [3]. Метою виробничої практики є оволодіння студентами сучасних методів та форм організації праці у галузі будівництва, отримання знань, професійних вмінь і навичок для прийняття самостійних рішень під час конкретної роботи в реальних умовах. Практика дає можливість закріпити та розширити теоретичні знання та придбати виробничі навички, ознайомитися $з$ призначенням, областями застосування, конструктивними особливостями, специфікою експлуатації машин і механізмів, засобів малої механізації; сучасними методами і засобами виконання основних технологічних процесів будівельних робіт; застосування матеріалів, конструкцій, машин, обладнання, інструментів; правилами техніки безпеки і охорони праці.

У сучасних умовах професійно-практична підготовка майбутніх будівельників покликана забезпечити багатопрофільність фахівця, його 


\section{СТВОРЕННЯТАВПРОВАДЖЕННЯ МОДЕЛІОРГАНІЗАЦЇ̈ПРАКТИКИ СТУДЕНТІВ БУДІВЕЛЬНИХ КОЛЕДЖІВ}

мобільність, готовність до зміни виду або змісту професійної діяльності. Для підготовки конкурентоспроможних фахівців необхідно створити добре організоване освітнє середовище. Ключові компетенції сучасного фахівця у галузі будівництва задаються основними замовниками - роботодавцями, державою і суспільством.

У наукових працях досліджено низку проблем моделювання процесів професійної підготовки (О. Дубинчук, М. Кадемія, Ю. Козловський, Н. Ничкало, В. Радкевич), інтегративних процесів у професійній освіті (М. Берулава, С. Гончаренко, Р. Гуревич, О. Стечкевич, Т. Якимович), професійної підготовки майбутніх будівельників (Б. Адабашева, О. Білик, О. Булейко, О. Гулай, Г. Гребенюк, І. Козловська, А. Литвин, М. Михнюк, К. Чудова, А. Цимбровський).

Мета статті полягає в розробці моделі організації практики студентів-будівельників.

Використання методу моделювання зумовлене необхідністю розв'язання тих завдань, які з різних причин не можугь бути вирішені іншим способом. До таких завдань належать і ті, що стосуються педагогічних систем. Процес дослідження реальних систем, що охоплює побудову моделі, дослідження ії властивостей і перенесення отриманих відомостей на реальну систему, називають моделюванням. При моделюванні використовується принцип аналогії, грунтуючись на якому в процесі наукового дослідження висуваються гіпотези, тобто передбачення, що будуються на відносно невеликій кількості дослідних даних, спостережень, інтуїтивних припущень, перевірка правильності яких здійснюється шляхом експерименту [1, 231].

Головним системотвірним чинником $є$ функції системи $[2,56]$. Проте $\epsilon$ кілька думок щодо того, що таке функція системи: перетворення ії входів у виходи; збереження існування системи, пї підтримки та впорядкованості; спосіб, засіб або дія для досягнення цілі (цілей) системи (ототожнюючи тим самим іiі із функціонуванням цієї ж системи).

Основна функція моделі полягає в тому, що іiі застосовують як: засіб пізнання; як засіб наукового осмислення дійсності; як інструмент прогнозування; як засіб постановки та проведення експериментальної перевірки. За допомогою моделі було впорядковано початкові уявлення щодо підготовки майбутніх будівельників. У процесі побудови моделі були виявлені істотні взаємозв'язки та залежності, послідовність дій (алгоритм) і необхідні ресурси. Насправді ця модель імітує процес підготовки, а інформація дає можливість зрозуміти те, яким чином досягався стан рівноваги в системі, підвищувалася якість професійної освіти.

На початковому етапі моделювання процес професійно-практичної підготовки розчленовують, щоб виявити змістово відокремлені його частини, а потім констатувати існування відносин цих частин у цілісній картині системи $[5,72]$.

Подальший крок у вивченні системи полягає в пошуках закономірностей системних відносин цілісного об'єкта. Спочатку визначають властивості, які характеризують зовнішні відносини системи в іiї цілісних проявах, а потім переходять до пошуку внутрішніх елементів та їхніх стійких відношень, які пов' язані з природою цілісних властивостей системи, що й дає змогу пояснити останні. У цьому виявляється застосування системного і структурного аналізів, які переплетені та невід'ємні один від одного

Розробка моделі організації практики майбутніх будівельників у коледжі відбувалося поетапно.

На першому етапі визначено й сформульовано актуальність проблеми. На другому етапі проблему піддали декомпозиції з тим, щоб накреслити комплекс завдань, виробити програму й методику дослідження, визначити критерії декомпозиції, за якими виокремлюються підсистеми, окреслюється зовнішнє середовище. На третьому етапі вивчено структуру системи, іiі функції та процеси, їхню специфіку. Четвертий етап полягав у формулюванні мети системи, декомпозиції цілей, їх узгодженні із засобами досягнення. На п’ятому та шостому етапах формулюються цілі різних рівнів ієрархії, виявляються зовнішні обмеження та потреби в ресурсах для реалізації цілей, здійснюється їх композиція. На шостому етапі необхідно було накреслити майбутнє (ресурси, цінності, технології тощо), тобто здійснити прогнозування. Сьомий етап передбачає оцінювання за встановленими критеріями різних чинників, що впливають на систему: соціальних, економічних, моральних тощо, а також кількісну оцінку цілей і ресурсів. Восьмий етап має на меті коригування цілей та порівняння різних варіантів розв'язання проблеми, приведення їх у відповідність 3 наявними ресурсами.

Важливим компонентом моделі є педагогічні умови організації практики майбутніх будівельників: уніфікація навчальних програм практики для підготовки за групою спеціальностей; інтегровані програми практики; використання інноваційних методик професійнопрактичної підготовки; узгодження програм різних 


\section{СТВОРЕННЯ ТАВПРОВАДЖЕННЯ МОДЕЛІОРГАНІЗАЦЇ ПРАКТИКИ}

СТУДЕНТІВ БУДІВЕЛЬНИХ КОЛЕДЖІВ

щаблів ступеневої освіти, організація навчального процесу за модулями професійних функцій.

У складних системах (якою є педагогічна система вищого закладу освіти) спостерігається узгоджена поведінка підсистем, які самоорганізовуються, від чого зростає рівень впорядкованості системи. Результатом самоорганізації стає взаємодія підсистем, яка завжди $є$ спільним проявом внутрішніх властивостей підсистем, а також впливом зовнішнього середовища.

Проходження виробничої практики відбувається на базах виробничих підприємств, 3 якими попередньо укладаються відповідні двосторонні угоди. Під час виробничої практики студентами вирішується низка завдань: засвоєння новітніх технологій організації виробництва; опанування прийомів та методів роботи із сучасними інструментами та контрольновимірювальними приладами; опрацювання питань з економіки, стандартизації та організації науководослідної і проектно-конструкторської роботи; вивчення питань охорони праці, правила техніки безпеки та шляхи збереження довкілля в процесі виробництва. Разом з тим, у моделі відображені особливості організації виробничої практики студентів-будівельників, варіативні види практики, форми і методи оцінювання результатів практики $[4,357]$.

Одним з варіантів виробничої практики майбутніх фахівців 3 будівництва на базі навчального закладу $є$ науково-дослідні будівельні лабораторії. Тут студенти долучаються до експериментальних досліджень та виконують будівельні завдання, зокрема, використання спеціального лабораторного обладнання та інструментальне обстеження реального об'єкту. Під час практики студенти навчаються користуватися спеціальними приладами та інструментами; виявляти дефекти у конструкціях та фіксувати їх; ознайомилися зі способами ремонту та відновлення будівель; набули навичок при вирішенні конкретного практичного завдання.

Останнім часом до зросла потреба у фахівцях, які здійснюють роботи з визначенням вартості виконаних будівельних робіт. Тому під час виробничої практики студентів-будівельників на базі навчального закладупропонуємо інноваційний вид професійно-практичної підготовки - експертну практику. Під час такої практики студенти освоюють особливості проведення будівельнотехнічних експертиз з питань визначення вартості будівельно-монтажних робіт із застосуванням підвищуючих коефіцієнтів, які враховують вплив умов проведення будівельних робіт. При проведенні таких експертиз необхідно досліджувати кошторисну та виконавчу документацію. Під час експертної практики проводиться дослідження виконавчих документів 3 визначенням вартості фактично виконаних робіт. Практикантам необхідно дослідити, чи були ці коефіцієнти передбачені проектом організації будівництва, дефектним актом або узгоджені 3 проектною організацією та замовником. У разі, якщо не подано документи про узгодження коефіцієнтів, треба дослідити, чи мали місце чинники, що ускладнюють проведення будівельномонтажних робіт. На будівництві діє низка чинників, що ускладнюють умови виробництва робіт, а саме: обмежені умови будівельного майданчика; рух будівельного транспорту й техніки вузькими проїздами в одній схемі 3 транспортом заводу, що діє; виконання монтажних робіт 3 “коліс" через відсутність майданчика для складування матеріалів; наявність об'єктів, що примикають і діють, вимагають застосування підвищених заходів та обмежень 3 метою захисту будівель від пошкодження, виключення можливого падіння матеріалів і виконання умов техніки безпеки; Тому при проведенні експертиз, пов'язаних 3 визначенням вартості фактично виконаних робіт, особливо на об'єктах, які фінансуються за рахунок державного бюджету, необхідно, крім виконаних обсягів, перевіряти також фактичні умови проведення робіт, наявність проекту організації будівництва, відповідних обгрунтувань та узгоджень із замовником і проектною організацією підвищуючих коефіцієнтів. Усі викладені факти дають підставу застосовувати до норм витрат праці будівельників і норм часу експлуатації машин наведені в збірниках ресурсних елементних кошторисних норм, які застосовуються для визначення потреби в матеріально-технічних і трудових ресурсах.

Це одним видом практики на базі комп’ютерної лабораторії $є$ робота 3 проектами у будівництві. Під час практики студенти опрацьовують будівельний проект, застосовуючи інструменти, техніки і методи запуску, планування, виконання, контролю і завершення проект, розбираючись в суті цих інструментів та принципах їх самостійно застосування на практиці. Для управління проектами в будівництві необхідно освоїти прикладне програмне забезпечення Microsoft Project Online та Office 365. Під час такої практики вивчаються питання ініціації проектів, інвестиційного та юридичного аналізу проектів в будівництві, організація процесів управління будівельними проектами, створення команди 


\section{СТВОРЕННЯТАВПРОВАДЖЕННЯ МОДЕЛІОРГАНІЗАЦІЇПРАКТИКИ СТУДЕНТІВ БУДІВЕЛЬНИХ КОЛЕДЖІВ}

проекту та побудова ефективної роботи команди. За результатами такої практики студенти зможуть самостійно здійснювати комплексне управління складними будівельними проектами; освоїти систему програмних продуктів Microsoft (Microsoft Project + Office 365 ) для управління проектами та автоматизації бізнес - процесів в проекті; здійснювати управління не тільки термінами проекту та об'ємами робіт, але й повноцінно керувати економікою та бюджетом проекту; підвищувати рентабельність проекту; створювати ефективну команду проекту та вирішувати конфліктні ситуації будь-якої складності при реалізації проекту; оволодіти навичками та інструментами 3 управління будівельними проектами; систематизувати наявні знання з управління проектами та отримати нові знання 3 передових методик управління проектами; розробляти план та графік будівельного проекту в Microsoft Project Professional; налаштовувати звіти по проектах в PowerBI; розраховувати інвестиційні дані по проекту; робити аудит виконання проекту та розробляти варіанти поліпшення планів реалізації проекту; “читати" креслення та розуміти кошториси; розробляти регламенти комунікацій між замовником, генпідрядником та підрядниками в проекті тощо.

Ще одним видом практики на базі навчального закладу є організація роботи молодіжного будівельного загону, робота якого спрямована на проведення різного роду будівельних та ремонтних робіт щодо підготовки закладу до нового навчального року.

Таким чином усі види практичної підготовки 3 майбутньої спеціальності сприяють самореалізації студентів. Щодо особливих професійних вимог до якостей майбутнього фахівця у галузі будівництва, то він повинен вміти: забезпечувати виробництво будівельно-монтажних робіт відповідно до проекту виробництва робіт, робочих креслень, вимог нормативних документів і термінів здачі об'єкту; організовувати роботу майстра 3 приймання і складування матеріалів, конструкцій, раціонального використання будівельних машин, транспортних засобів, розстановки і видачі завдань бригадам і ланкам; контролювати послідовність роботи, усуваючи порушення технології і забезпечуючи якість будівельномонтажних робіт; контролювати дотримання вимог з охорони праці, протипожежної безпеки, захисту довкілля; користуватися покажчиком державних стандартів та нормативною документацією. Молодший бакалавр у галузі будівництва повинен знати: технологію та організацію будівельного виробництва, проектнокошторисну документацію на об'єкти, що будуються, будівельні норми і правила на виробництво і приймання будівельно-монтажних робіт; конструктивні рішення будівель і споруд, основи розрахунку будівельних конструкцій; трудове законодавство, правила і норми з охорони праці, шляхи захисту довкілля; економіку, організацію праці, планування роботи на ділянці, основи управління трудовим колективом, єдині норми і розцінки, чинні положення про оплату праці.

Таким чином проаналізувавши підготовку майбутніх будівельників у коледжах ми виявили такі особливості різних видів виробничої практики. Розглядаючи особливості щодо організації виробничої практики під час підготовки молодшого бакалавра у галузі будівництва на основі власного досвіду нами виявлено, що усі види практик повинні відповідати вимогам поетапності, інтегративності, ступеневості та неперервності. Зокрема, особливості організації виробничої практики зумовлені оптимізацією зв'язків 3 виробництвом, врахуванням сучасних вимог ринку праці; впровадженням сучасних технологій будівництва тощо.

Для оцінки моделі організації практики вона була запропонована для огляду експертам, викладачам і студентам. Експериментально підтверджено, що розроблена модель організації практики майбутніх будівельників служить для отримання високих результатів практичного навчання. Отримані у ході експерименту результати показують ефективність моделі та дієвість зв'язків між її елементами. Під час проведення експерименту в експериментальних групах вищими виявились повнота знань, доцільність, сформованість і різнобічність умінь.

Висновки. Таким чином, розробка та впровадження моделі організації практики майбутніх будівельників у коледжах дозволяє забезпечити логічну послідовність вибору напрямів діяльності майбутніх будівельників, сприяє утворенню комплексу професійно спрямованих умінь і навичок необхідних для виконання професійних функцій.

Перспективи подальших розвідок вбачаємо у перевірці ефективності авторської програми виробничої практики.

\section{ЛІТЕРАТУРА}

1. Козловський Ю. М. Моделювання наукової діяльності вищого навчального закладу: теоретико- 
методологічний аспект:[Монографія]/Ю.М.Козловський. - Львів: СПОЛОМ, 2012. -484 с.

2. Кустовська О. В. Методологія системного підходу та наукових досліджень / О. В. Кустовська. - Тернопіль: Економічна думка, 2005. - 124 с.

3. Про проведення практики студентів вищих навчальних закладів України: Наказ М-ва освіти і науки України наказ 351 від від 20.12.94.

4. Якимович Т.Д., Макогін О.В. Форми і методи оцінювання результатів виробничої практики/Т.Д. Якимович, О.В.Макогін // Сучасні інформаційні технології та інноваційні методики навчання упідготовці фахівців: методологія, теорія, досвід, проблеми: зб. наук. пр. 2016 - Вип. 45. - Київ; Вінниця: ТОВ фірма "Планер”, 2016. - C. 355-359.

5. Якимович, Т. Д. Основи дидактики професійнопрактичної підготовки: навчально-методичний посібник [Текст] / Т. Д. Якимович. - К.: Педагогічна думка, 2013. $-136 \mathrm{c}$.

\section{REFERENCES}

1. Kozlovskyy, Yu. M. (2012). Modelyuvannya naukovoyi diyalnosti vyshchoho navchalnoho zakladu: teoretyko-metodolohichnyy aspect [Modeling of scientific activity of a higher educational institution: theoretical and methodological aspect]. Lviv: SPOLOM, 484 p. [in Ukrainian].

2. Kustovsk, O. V. (2005). Metodolohiya systemnoho pidkhodu ta naukovykh doslidzhen [Methodology of system approach and scientific research]. Ternopil: Ekonomichna dumka, 124 p. [in Ukrainian].

3. Pro provedennya praktyky studentiv vyshchykh navchalnykh zakladiv Ukrayiny [About practice of students of higher educational institutions of Ukraine]. Order of the Ministry of Education and Science of Ukraine Order 351 from dated December 20 [in Ukrainian].

4. Yakymovych, T. D. \& Makohin, O.V. (2016). Formy i metody otsinyuvannya rezultativ vyrobnychoyi praktyky [Forms and methods for evaluating the results of industrial practice]. Modern information technologies and innovative methods of training in the training of specialists: methodology, theory, experience, problems. Kyiv Vinnytsya: TOV firma "Planer", no. 45, pp. 355-359. [in Ukrainian].

5. Yakymovych, T. D. (2013). Osnovy dydaktyky profesiyno-praktychnoyi pidhotovky: navchalnometodychnyy posibnyk [Fundamentals of didactics of vocational and practical training]. Kyiv: Pedahohichna dumka, 136 p. [in Ukrainian].

Стаття надійшла до редакції 31.07.2018

УДК 7.01(477)“19”

DOI:

Людмила Волотко, викладач кафедри культурологї̈ та мистеиької освіти Дрогобиџького державного педагогічного університету імені Івана Франка

\section{ГЕНЕЗИС УКРАЇНСЬКОГО МИСТЕЦЬКОГО АВАНГАРДУ}

Статтю присвячено осмисленню філософських засад українського мистеитвва початку 20 століття; розглянуто генезис украӥнського авангарду: причини його виникнення; сутність та особливості, історію становлення; досліджено різноманітні напрямки украӥнського авангардного мистецтва: кубізм, футуризм, супрематизм, абстракціонізм, конструктивізм з позиції різних українських мистиів - О. Богомазова, О. Архипенка, О. Екстер, К. Малевича, В. Кандинського, В. Срмілова.

Ключові слова: украӥнських авангард; авангардний живопис; кубізм, футуризм; кубофутуризм; абстракиіонізм; супрематизм; конструктивізм.

Jim. 7.

Lyudmyla Volotko, Lecturer of the Culturology and Artistic Education Department Drohobych Ivan Franko State Pedagogical University

\section{THE GENESIS OFTHE UKRAINIAN ARTISTIC AVANT-GARD}

The article is devoted to the comprehension of the philosophical foundations of Ukrainian art of the early 20th century. It investigates the genesis of Ukrainian avant-garde - the direction in art, which destroyed the traditional principles of art creativity. The article reveals the reasons for its rise, the essence and features of avantgarde painting. Its basis are the form destruction and colour esterification, and thus the destruction of human existence. The history of the Ukrainian avant-garde is considered, it has passed two important stages: acquaintance with the latest trends of world culture and their rethinking (1907 - 1914); the artists' creative search for the meaning of existence of a modern person embodied in painting, sculpture, architecture, literature and theatre (20th years of the 20th century). Various directions of Ukrainian avant-garde art are investigated. They are: cubism, futurism, suprematism, abstractionism, constructivism to the opinion of various Ukrainian artists - O. Bohomazov, O. Arkhypenko, O. Ekster (representatives of Ukrainian cubofuturizm), K. Malevych (the founder of suprematism), $V$. Kandynskiy (abstractionism), V. Yermilov (constructivism). The creativity of each of them is reflection on the artistic and aesthetic content of the art of avant-garde and the essence of the main art categories: "colour", "line", 